\title{
Population increase and synurbization of the yellow-necked mouse Apodemus flavicollis in some wooded areas of Warsaw agglomeration, Poland, in the years 1983-2018
}

\author{
Grzegorz Lesiński $^{1} \cdot$ Jakub Gryz $^{2} \cdot$ Dagny Krauze-Gryz $^{3} \cdot$ Przemysław Stolarz $^{4}$ \\ Published online: 25 August 2020 \\ (C) The Author(s) 2020
}

\begin{abstract}
Studies on the contribution of the yellow-necked mouse Apodemus flavicollis and of other vertebrates to the diet of the tawny owl Strix aluco were carried out in Warsaw (central Poland) in the years 1983-2018. The frequency of the yellow-necked mouse in owl pellets increased at the break of the 20th and 21st centuries, particularly in some woodlands in the peri-urban area of the agglomeration. In the second half of the first decade of the twenty-first century, this mouse species colonised a park in the city centre. The yellow-necked mouse may become an important competitor for the synurbic population of the striped field mouse Apodemus agrarius.
\end{abstract}

Keywords Urban environment $\cdot$ City park $\cdot$ Suburban forest $\cdot$ Synurbization $\cdot$ Terrestrial rodents $\cdot$ Central Europe

\section{Introduction}

Studies on small terrestrial mammals inhabiting urban areas have been carried out in various regions of the world (Andrzejewski et al. 1978; Dickman and Doncaster 1987; Goszczyński et al. 1993; Chernousova 1996; Baker et al. 2003; Mahan and O’Connel 2005; Gryz et al. 2008; Cavia et al. 2009; Garden et al. 2010; Gomes et al. 2011; Khlyap et al. 2012; Lopucki et al. 2013; Klimant et al. 2017; Łopucki and Kitowski 2017). These groups of animals, which have relatively low dispersal abilities, find it difficult to penetrate areas strongly modified by human activity. Animals are particularly threatened by habitat fragmentation (Angold et al. 2006; Vergnes et al. 2013; Gomes et al. 2011; Gryz et al. 2017b) and road mortality (Hodson 1960; Bąkowski and Kozakiewicz 1988; Orłowski and Nowak 2006;

Grzegorz Lesiński

glesinski@wp.pl

1 Faculty of Animal Sciences, Warsaw University of Life Sciences SGGW, Ciszewskiego 8, 02-786 Warsaw, Poland

2 Department of Forest Ecology, Forest Research Institute, Sęocin Stary, Braci Leśnej 3, 05-090 Raszyn, Poland

3 Department of Forest Zoology and Wildlife Management, Warsaw University of Life Sciences - SGGW, Nowoursynowska 159C, 02-787 Warsaw, Poland

4 Centre of Human Ecology, Kościuszki 24, 05-075 Warsaw, Poland
Gryz and Krauze 2008). Therefore, the centres of large urban agglomerations host few small mammal species (Goszczyński et al. 1993; McKinney 2008; Buckmaster et al. 2010). Moreover, native species are more sensitive to urbanization than alien species (Cavia et al. 2009).

The yellow-necked mouse Apodemus flavicollis (Melchior, 1834), widespread in most parts of Europe and the Middle East (Amori et al. 2016), is a species associated with woodlands and mature forests (Pucek et al. 1993, Mazurkiewicz and Rajska-Jurgiel 1998; Marsh and Harris 2000; Juškaitis 2002), where it often dominates the terrestrial rodent communities (Pucek et al. 1993; Mazurkiewicz and Rajska-Jurgiel 1998), but prefers forest edges (Montgomery 1999; Hille and Mortelliti 2010). It is a ground dwelling species with a high capacity for climbing trees (Štěpánková and Vohrálik 2009) and frequently occupies bird nest boxes (Juškaitis 2000). The yellow-necked mouse is typically nocturnal (Wójcik and Wołk 1985) and its home range size is approximately $0.4-5$ ha (Stradiotto et al. 2009). The species has a broad food niche that includes plants, fungi and animal prey (Drożdż 1966; Abt and Bock 1998). This species sometimes but rarely penetrates habitats modified by human activity, such as agrocoenoses (Hoffmeyer 1973; Popov 1993) and urban areas, e.g., in Vienna, the yellow-necked mouse has been reported to occur in parks and green spaces (Mitter et al. 2015). During density peaks, caused by oak mast years, the species also migrates to arable land and orchards (Gryz et al. 2019; Gryz and Krauze-Gryz 2019). 
During the recent decades, large city agglomerations in Poland have been often colonized by striped field mouse Apodemus agrarius (Pallas, 1771), which in city parks (also in Warsaw) forms quite abundant populations (Andrzejewski et al. 1978). In the past decade, the effects of synurbization (= urbanization) were also observed in the yellow-necked mouse, whose presence was recorded in several city parks situated only several kilometres from the centre of Warsaw (Gortat et al. 2014, 2016; Krauze-Gryz et al. 2016). One may thus expect interactions between the two sympatric species (Simenowska-Nikolova 2007).

Apart from standard trapping methods, the analysis of predator diets is a method for studying rodents. The undigested remains contained in owl pellets provide valuable information on their small mammal prey species (Heisler et al. 2015). Many species of owls are opportunistic predators, which mean that the frequency of hunting for specific prey is correlated with its density in a given area (Pérez-Barbería 1991). Therefore, pellets can be used to assess the relative abundances of small mammal species (Andrade et al. 2016). The diet of tawny owl Strix aluco is largely determined by the structure of local prey communities (Wendland 1980; Lesiński et al. 2009). Moreover, the owl is a sedentary species (Mebs and Scherzinger 2000) with individual home ranges covering several tens of hectares (Redpath 1995; Sunde and Bølstad 2004).

The aim of this study was to evaluate the current degree of synurbization of the yellow-necked mouse in Warsaw and to determine how its contribution to urban rodent communities has changed over the recent decades. We also investigated whether the contributions of a strongly synurbic species the striped field mouse - had changed in the Warsaw agglomeration. In this study, we used pellets that collected from 1983 to 2018 .

\section{Study area and methods}

The study was carried out in the city agglomeration of Warsaw (central Poland), which is inhabited by approximately 2 million people, and in some forests outside the city. The diet of the tawny owl was analysed at ten sites: one situated in the centre of the city, five in the peri-urban zone and four outside the agglomeration (Fig. 1). Central zone is characterized by the presence of dense built-up areas, while in peri-urban zone there are more large wooded areas (Fig. 2).

The sites are described as follows:

Lazienki - city central park ( $2 \mathrm{~km}$ from the city centre) of an area of 80 ha. The area is dominated by 40 - to $150-$ year-old woodlands, extended lawns and artificial bodies of water. Numerous historical buildings are situated in the park. Due to its historical character, the park is protected as a national heritage site and the area is frequented by many people.

Bielany - a peri-urban forest ( $7 \mathrm{~km}$ from the city centre) an area of 130 ha that since 1978 has been protected as a multi-species broad-leaved woodland. Habitats in this reserve include oak-lime-hornbeam forest, riparian forest and alder carr. The protection of the woodland extends to a rather large area of approximately 170 ha. The oldest oak stands exceed 250 years of age. The reserve area is crossed by two small watercourses. On the eastern side, the reserve is partly separated from the Vistula River by a 3-lane expressway. In contrast, urban development is present to the west and south.

Sobieski - a peri-urban woodland reserve $(10 \mathrm{~km}$ from the city centre) protected since 1934 and covering 115 ha. The central and southern parts retain oak tree stands that are over 170 years old, while other areas have stands dominated by oaks and Scots pines with a mix of various broad-leaved species. The reserve is part of a larger forest complex covering approximately 700 ha. This area, which lacks natural watercourses or bodies of water, is connected to a limited degree with the extensive forest areas located beyond the Warsaw city limits.

Tarchomin - a small (approximately $8 \mathrm{ha}$ ) peri-urban park (10 km from the city centre) surrounded by highdensity housing and adjacent on one side to old-growth riparian forests growing along the Vistula River. There are dispersed old-growth stands mainly comprising deciduous trees; denser tree stands are situated near the buildings. There are also small water bodies.

Młociny - a peri-urban woodland $(11 \mathrm{~km}$ from the city centre) with an area of approximately $1 \mathrm{~km}^{2}$, partly of a park character. On the east, the area borders the Vistula River (narrow strip of mature alder wood) and on the south - an exclusive residential district. The tree stands were mostly mixed-species stands, and in many places were older than 100 years.

Buchnik - a peri-urban forest (15 km from the city centre) built largely by mature broad-leaved tree stands (hornbeam, oak) adjacent to residential areas and to the Vistula River valley. Owl pellets were collected under trees, mainly under holes in deciduous species (hornbeam, oak), which were used as nesting and resting places. Distance from city centre - ca. $15 \mathrm{~km}$.

Dziekanów Leśny - a forest outside city (19 km from the city centre), eastern edge of the Kampinos Forest, a large (approximately 30 thousand ha) forest complex protected as a national park. The tree stands are mainly composed of pine and mixed forests bordering dispersed building developments. Several hundred metres from the buildings, there are fragments of alder woods and small deciduous forests. 
Fig. 1 Distribution of sites of the tawny owl involved in the longterm study in Warsaw agglomeration: 1 - Młociny, 2 - Bielany, 3

- Buchnik, 4 - Tarchomin, 5 -

Sobieski, 6- - Lazienki and outside the city: 7 - Rogów, 8 -

Dziekanów Leśny, 9 - Klembów,

10 - Natolin near Nur

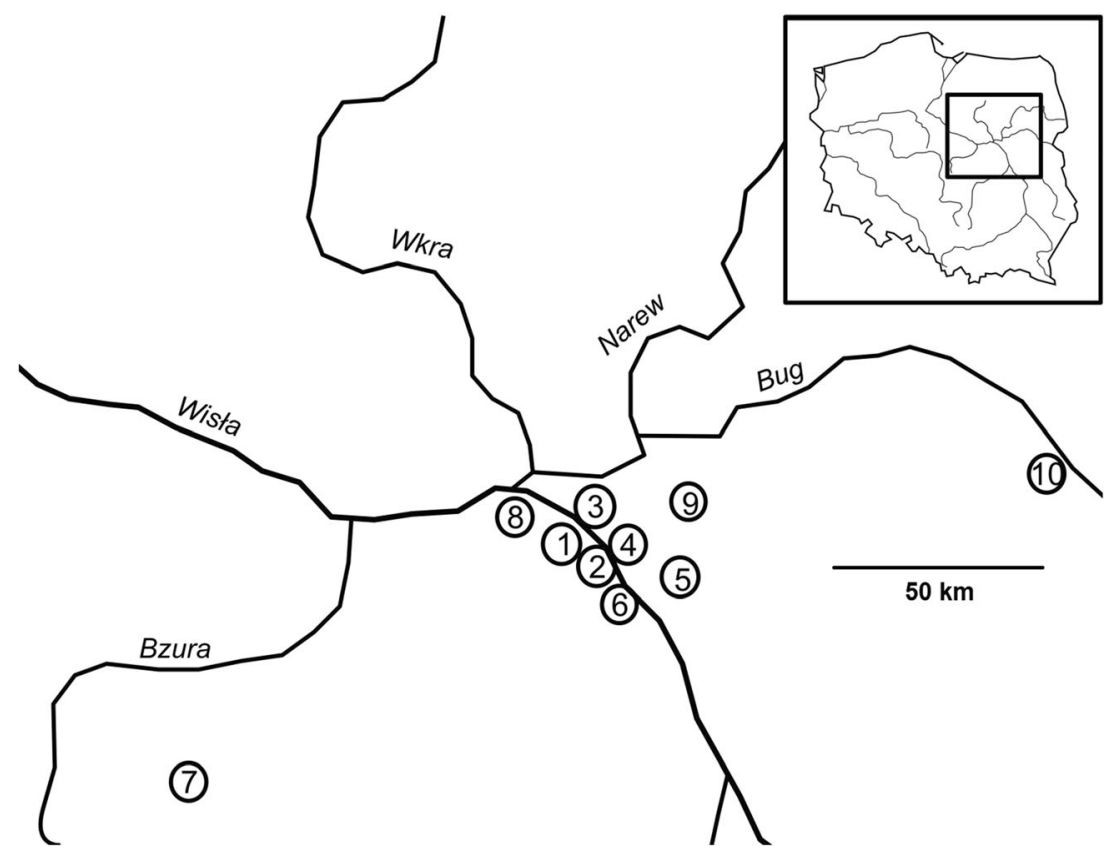

Klembów - old-growth hornbeam deciduous forest outside city ( $35 \mathrm{~km}$ from the city centre) protected in nature reserve "Dębina" with an area of approximately 50 ha. The tree stand is composed of many 200-year-old hornbeam and oak trees. The nature reserve is surrounded by pine forests in coniferous habitats.

Rogów - a forest outside city ( $90 \mathrm{~km}$ from the city centre) with a study area covering $105 \mathrm{~km}^{2}$ of a field-forest
Fig. 2 Main wooded areas in Warsaw agglomeration. Dashed line is a border of central zone

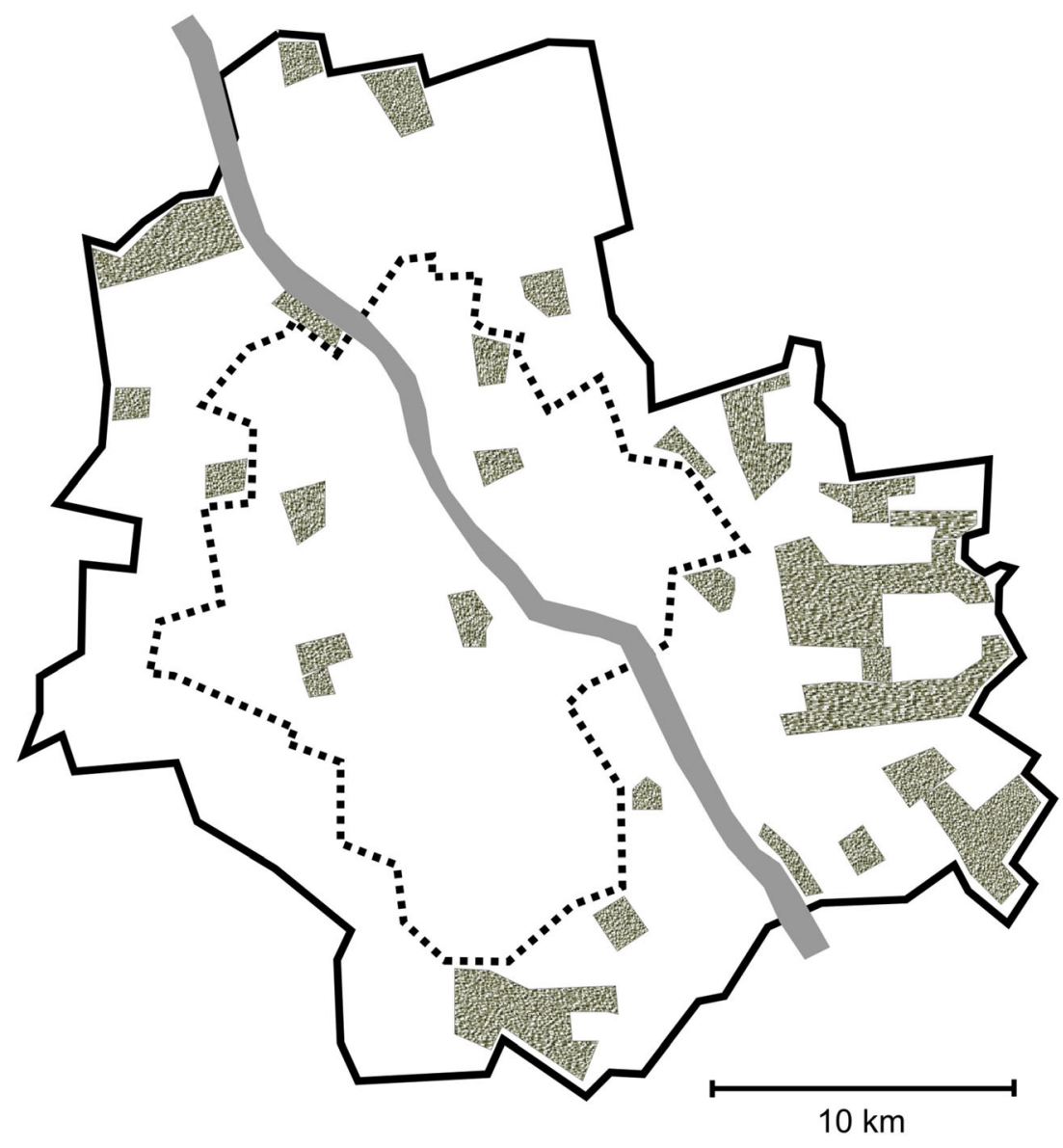


Table 1 Study sites and years when owl pellets were collected

\begin{tabular}{lll}
\hline Site & Type of site & Study years \\
\hline Młociny & Peri-urban & $1983-1984,2007-2018$ \\
Bielany & Peri-urban & $1984,2007-2018$ \\
Buchnik & Peri-urban & $2007-2018$ \\
Tarchomin & Peri-urban & $2008-2018$ \\
Sobieski & Peri-urban & $1995-1996,2009,2014-2018$ \\
Łazienki & Urban & $2004-2008,2009,2012-2018$ \\
Rogów & Nonurban & $2004-2008,2010-2018$ \\
Dziekanów Leśny & Nonurban & $1984,2000-2007$ \\
Klembów & Nonurban & $2007-2018$ \\
Natolin near Nur & Nonurban & $2004-2018$ \\
\hline
\end{tabular}

mosaic, where forests occupy approximately $24 \%$ of the area growing in 8 forest complexes of an area from 70 to 1000 ha. The main forest-forming species was Scots pine, which dominated $50 \%$ of the forested area. The contribution of oak was more than $20 \%$ and that of beech was almost $10 \%$. The main habitat types were mixed fresh forest and fresh forest. The remaining parts of the area were occupied by arable lands (59\%) and to a lesser extent by orchards, permanent grasslands and dispersed building developments.

Natolin, near Nur - an edge of a forest complex outside city (110 km from the city centre) called the Sterdyn Forest, with an area of $25 \mathrm{~km}^{2}$. The tree stand adjacent to the site is dominated by 40 - to 60 -year-old pine trees; in some places, there are small fragments of more fertile forests with oaks and hornbeams. The forest borders small arable lands, a small village and large flooded meadows in the Bug River valley.

Pellets were collected irregularly throughout many years (Table 1) usually a few times per year. Pellets were soaked in water to extract diagnostic bone remains. The rodents of the genus Apodemus were determined to species based on the skulls using the keys edited by Pucek (1981) and the descriptive criteria given by Ruprecht (1979). The yellow-necked mouse was distinguished from the striped field mouse based on the morphology of the cusps on $\mathrm{M}^{1}$ and $\mathrm{M}^{2}$ and the structure of the upper side of the skull. Moreover, the proportion of the length of the foramen incisivum to the length of diastema was also considered. The yellow-necked mouse was distinguished from the wood mouse based on the length of the upper molar rows, the width of $\mathrm{I}^{1}$, the crown width of $\mathrm{M}^{1}$, the proportion of the length of the foramen incisivum to the length of the diastema and on the depth of the foramen infraorbitale.

Three study periods were distinguished: 1983-1984, 1995-2009 and 2010-2018. Both partially published data from the analysis of owl diets in the study area (Goszczyński et al. 1993; Lesiński and Stolarz 1999; Gryz et al. 2008; Lesiński and Gryz 2012; Gryz et al. 2017b) and unpublished data were used.

Data were expressed as percent relative frequency (number of individuals of each species / total number of individuals). Chi-square $\chi^{2}$ tests for $2 \times 2$ contingency tables with Yates' correction were used to compare of the raw frequency data of each species remains. Spearman's $\left(r_{s}\right)$ correlation coefficient was used to analyse the year-to-year variation in the ratio of yellow-necked mice to striped field mice. Significance level $\alpha=0.05$. Statistica 12 software was used for calculations.

\section{Results}

When comparing the contributions of the yellow-necked mouse and striped field mouse to owl diets during two study periods (1995-2009 and 2010-2018), we found differences between areas situated in the city and outside the city. In the city the first species showed increasing trend, while decreasing trend outside the city. The contribution of striped field mouse decreased in the city and showed no significant changes outside the city (Table 2 ).

Within the Warsaw agglomeration in the case of yellownecked mouse we found an increasing trend for the central zone and for three areas in the peri-urban zone. In two periurban areas and in one site outside of the city, we either found a decline in the contribution of the yellow-necked mouse or

Table 2 Changes in the proportion of Apodemus flavicollis (Af) and Apodemus agrarius (Aa) to other vertebrate prey of the tawny owl in wooded areas of Warsaw city agglomeration and outside the city in the years 1995-2009 and 2010-2018

\begin{tabular}{lllllllll}
\hline Area & $\begin{array}{l}\text { 1995-2009 Af: } \\
\text { remaining prey }\end{array}$ & $\begin{array}{l}\text { 2010-2018 Af: } \\
\text { remaining prey }\end{array}$ & $\mathrm{Chi}^{2}$ & $\begin{array}{l}\text { Significance of } \\
\text { differences Trend }\end{array}$ & $\begin{array}{l}\text { 1995-2009 Aa: } \\
\text { remaining prey }\end{array}$ & $\begin{array}{l}\text { 2010-2018 Aa: } \\
\text { remaining prey }\end{array}$ & $\begin{array}{c}\mathrm{Chi}^{2} \\
\text { Significance of } \\
\text { differences Trend }\end{array}$ \\
\hline $\begin{array}{l}\text { City (6 sites) } \\
\begin{array}{l}\text { Outside the } \\
\text { city (3 } \\
\text { sites) }\end{array}\end{array}$ & 690: 2505 & $606: 3292$ & $\mathbf{4 2 . 6 3}$ & $\boldsymbol{P}<\mathbf{0 . 0 0 1} \downarrow$ & $104: 3091$ & 103: 3795 & 2.12 & $P=0.127$ \\
\hline
\end{tabular}

Differences statistically important in bold. $\uparrow$ - upward trend, $\downarrow-$ downward trend 
Table 3 Changes in the proportion of Apodemus flavicollis (Af) and Apodemus agrarius (Aa) to other vertebrate prey of the tawny owl in wooded areas of Warsaw agglomeration and in sites outside the city in the years 1995-2009 and 2010-2018

\begin{tabular}{|c|c|c|c|c|c|c|c|c|}
\hline Site (location) & $\begin{array}{l}\text { 1995-2009 Af: } \\
\text { remaining prey }\end{array}$ & $\begin{array}{l}\text { 2010-2018 Af: } \\
\text { remaining prey }\end{array}$ & $\mathrm{Chi}^{2}$ & $\begin{array}{l}\text { Significance of } \\
\text { differences Trend }\end{array}$ & $\begin{array}{l}\text { 1995-2009 Aa: } \\
\text { remaining prey }\end{array}$ & $\begin{array}{l}2010-2018 \mathrm{Aa} \\
\text { remaining prey }\end{array}$ & $\mathrm{Chi}^{2}$ & $\begin{array}{l}\text { Significance of } \\
\text { differences Trend }\end{array}$ \\
\hline $\begin{array}{l}\text { Łazienki } \\
\text { (CC) }\end{array}$ & $0: 329$ & $31: 344$ & 26.52 & $P<0.001 \uparrow$ & $61: 268$ & 47: 328 & 4.41 & $P=0.036 \downarrow$ \\
\hline $\begin{array}{l}\text { Tarchomin } \\
\text { (PU) }\end{array}$ & $2: 264$ & 144: 1065 & 22.90 & $P<0.001 \uparrow$ & 49: 217 & 181: 1027 & 1.70 & $P=0.192$ \\
\hline Buchnik (PU) & 13: 468 & 163: 1219 & 33.42 & $P<0.001 \uparrow$ & 177: 304 & 177: 1205 & 131.88 & $P<0.001 \downarrow$ \\
\hline Sobieski (PU) & $2: 156$ & 240: 726 & 43.30 & $P<0.001 \uparrow$ & 10: 148 & 100: 866 & 2.05 & $P=0.152$ \\
\hline Bielany (PU) & 85: 144 & 126: 336 & 6.54 & $P=0.011 \downarrow$ & 14: 215 & 26: 436 & 0.01 & $P=0.933$ \\
\hline Młociny (PU) & 43: 129 & 72: 419 & 8.78 & $P=0.003 \downarrow$ & $17: 155$ & 41: 450 & 0.21 & $P=0.649$ \\
\hline $\begin{array}{l}\text { Klembów } \\
\text { (OC) }\end{array}$ & 170: 784 & 323: 1973 & 7.08 & $P=0.008 \downarrow$ & 32: 922 & 63: 2233 & 0.68 & $P=0.409$ \\
\hline $\begin{array}{l}\text { Natolin n. } \\
\quad \text { Nur (OC) }\end{array}$ & 95: 776 & 78: 907 & 4.54 & $\boldsymbol{P}=\mathbf{0 . 0 3 3} \downarrow$ & $8: 863$ & 9: 976 & 0.05 & $P=0.816$ \\
\hline Rogów (OC) & 425: 945 & 205: 412 & 0.85 & $P=0.355$ & 64: 1306 & $31: 586$ & 0.05 & $P=0.820$ \\
\hline
\end{tabular}

Differences statistically important in bold. CC - city centre, PU - peri-urban zones, OC - outside city areas, $\uparrow$ - upward trend, $\downarrow-$ downward trend

noted no changes (Table 3, Fig. 3). In only two sites (Lazienki - central zone and Buchnik - peri-urban zone), the striped field mouse decreased in the diet of the tawny owl. No statistically significant changes were noted in the other areas (Table 3).

Differences (increasing trend) were found in the peri-urban sites (Młociny, Bielany) when comparing the contribution of the yellow-necked mouse to the diet of the tawny owl between the periods 1983-1984 and 1995-2009 (Table 4, Fig. 3). At the same sites, the contribution of the striped field mouse decreased in the Bielany site and did not change in Młociny. In the area farther from the city (Dziekanów Leśny), no significant changes in the contributions of either rodent species to the owl diets were noted during the same time period.
The yellow-necked mouse was found in the diet of the tawny owl in Łazienki Park (city centre) in 2013; until 2018, its contribution among vertebrate prey varied from 0.02 to 0.15 ( 0.09 on average). In the years 2008-2012, this species was not found, but the collected samples were very small (2-9 vertebrate prey items). The yellow-necked mouse was not present in the owl diets in the years 2004-2007, although the sample sizes were markedly larger (30-156 vertebrate prey items) (Table 5).

In the last 6 years of the study, the yellow-necked mouse was less numerous than the striped field mouse in Lazienki Park. The proportion of the yellow-necked mouse in the years 2013-2018 varied from 0.05 to 0.67 (0.29 on average) (Table 5) and showed an increasing albeit statistically insignificant $\left(n=6, \mathrm{r}_{\mathrm{s}}=0.58, p=0.23\right)$ trend.

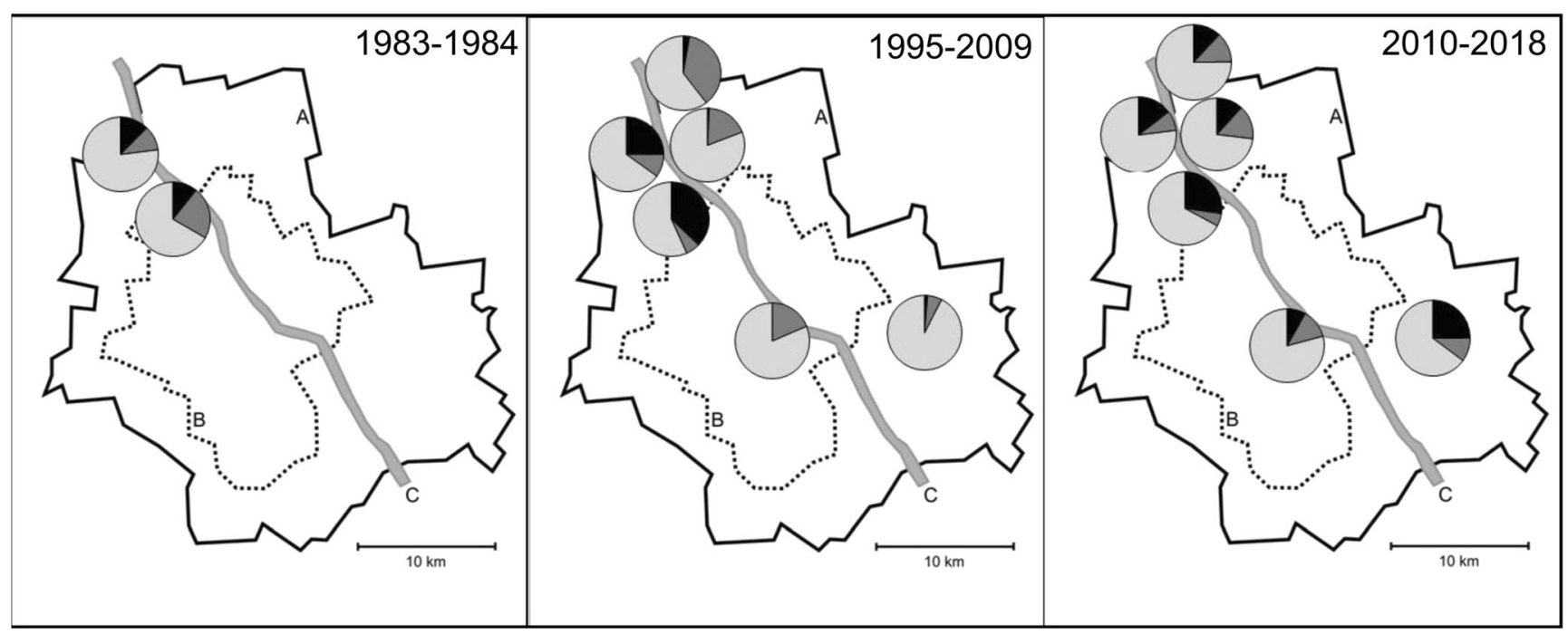

Fig. 3 Contribution of Apodemus flavicollis (black), A. agrarius (dark grey) and other vertebrate species (light grey) in owls' diet in peri-urban (a) and central (b) zones (c) Vistula river 
Table 4 Changes in the proportion of Apodemus flavicollis (Af) and Apodemus agrarius (Aa) to other vertebrate prey items of the tawny owl in two peripheral sites and in one outside the city between the years 1983-1984 and 1995-2009

\begin{tabular}{lllllllll}
\hline Site (location) & $\begin{array}{l}\text { 1983-1984 Af: } \\
\text { remaining prey }\end{array}$ & $\begin{array}{l}\text { 1995-2009 Af: } \\
\text { remaining prey }\end{array}$ & Chi $^{2}$ & $\begin{array}{l}\text { Significance of } \\
\text { differences Trend }\end{array}$ & $\begin{array}{l}\text { 1983-1984 Aa: } \\
\text { remaining prey }\end{array}$ & $\begin{array}{l}\text { 1995-2009 Aa: } \\
\text { remaining prey }\end{array}$ & $\begin{array}{c}\text { Chi }^{2} \\
\text { Significance of } \\
\text { differences Trend }\end{array}$ \\
\hline Bielany (PU) & 10: 83 & $85: 144$ & $\mathbf{2 0 . 8 6}$ & $\boldsymbol{P}<\mathbf{0 . 0 0 1} \uparrow$ & $21: 72$ & $14: 215$ & $\mathbf{1 6 . 8 5}$ & $P<0.001 \downarrow$ \\
Młociny (PU) & $34: 230$ & $43: 129$ & $\mathbf{9 . 7 1}$ & $\boldsymbol{P}=\mathbf{0 . 0 0 2} \uparrow$ & $29: 235$ & $17: 155$ & 0.04 & $P=0.837$ \\
$\begin{array}{c}\text { Dziekanów } \\
\text { Leśny (OC) }\end{array}$ & $5: 124$ & $4: 113$ & 0.02 & $P=0.881$ & $5: 124$ & $1: 116$ & 1.26 & $P=0.263$ \\
\hline
\end{tabular}

Abbreviations as in Table 1

\section{Discussion}

In recent decades, synurbization in the Warsaw agglomeration has involved several species of vertebrates, especially birds such as the fieldfare Turdus pilaris (Nowicki 2001), magpie Pica pica (Lesiński 1998; Luniak et al. 2001), hooded crow Corvus cornix (Wegrzynowicz 2013), and by mammals such as the parti-coloured bat Vespertilio murinus (Lesiński et al. 2001) or the fox Vulpes vulpes (Gryz et al. 2017a).

Species of the genus Apodemus show different degrees of synurbization throughout Europe. In Great Britain, it is the wood mouse that undergoes synurbization (Dickman and Doncaster 1987). The same is true for this species in the Czech Republic and Germany - see the examples from Prague (Mikulová and Frynta 2001) and from Berlin (Elvers and Elvers 1984). In Polish towns, synurbization is often shown by the striped field mouse, such as in Warsaw (Andrzejewski et al. 1978) or in Lublin in eastern Poland (Wiaccek et al. 2009). The latter species is also dominant in the small mammal communities in Russian Yekaterinburg (Ural) (Chernousova 1996) and in some urban areas of the European part of Russia (Khlyap et al. 2012). The yellownecked mouse is rarely frequent in cities such as Vilnius (Baranauskas et al. 2005) and Vienna (Mitter et al. 2015).
In wooded areas of the peri-urban zones of Warsaw, the yellow-necked mouse has shown a marked increase in population densities, and the results of our studies show that the process probably started earlier in north-western part of Warsaw agglomeration (Młociny, Bielany - in 1983-1984 its contribution was more than $10 \%$ - Table 4, Fig. 3) than in the eastern part (Buchnik, Tarchomin, Sobieski - even in years 1995-2009 its contribution was much lower than 5\% Table 3, Fig. 3). In the first two sites, the rise of the number of mice ended at the end of the twentieth century, while in the eastern part of the city, it lasted during the first two decades of the twenty-first century. Notably, different trends were demonstrated in sites situated on opposite banks sides of the Vistula River: Młociny and Bielany on the left bank and Buchnik and Tarchomin on the right bank (Figs. 1 and 3). This may suggest that this large river (300-500 m wide) may be an important barrier hindering the exchange of individuals in populations of small rodents.

Overcrowding of the population in the peri-urban zones and in suburbia is an important phenomenon stimulating the start of synurbization. This was described for some animals that had already previously formed city populations, such as the woodpigeon Columba palumbus (Tomiałojć 1976). The same mechanism most likely operates in the case of the
Table 5 Presence of the yellownecked mouse (Af) in the diet of the tawny owl from Łazienki Park (central part of the city) and the ratio of the yellow-necked to striped field mice (Aa) in the years (Aa) w latach 2004-2018

\begin{tabular}{llcl}
\hline Year & N vertebrate prey & $\begin{array}{l}\text { N Af (share among } \\
\text { vertebrate prey) }\end{array}$ & N Af/N Aa \\
\hline 2004 & 41 & 0 & 0 \\
2005 & 156 & 0 & 0 \\
2006 & 97 & 0 & 0 \\
2007 & 30 & 0 & 0 \\
2008 & 2 & 0 & 0 \\
2009 & 3 & 0 & 0 \\
2012 & 9 & 0 & 0 \\
2013 & 92 & $5(0.05)$ & 0.19 \\
2014 & 80 & $12(0.15)$ & 0.38 \\
2015 & 49 & $1(0.02)$ & 0.05 \\
2016 & 14 & $2(0.14)$ & 0.67 \\
2017 & 48 & $5(0.10)$ & 0.38 \\
2018 & 56 & $5(0.09)$ & 0.50 \\
\hline
\end{tabular}


yellow-necked mouse in Warsaw. In the central part of the Warsaw agglomeration (Lazienki), the yellow-necked mouse was not found either at the beginning of the 1990s (Goszczyński et al. 1993) or in 2006 (Gryz et al. 2008). It was first recorded during trapping surveys in the green areas of Warsaw (including Łazienki) in the years 2010-2011 (Gortat et al. 2014). In the diet of the tawny owl, it was identified 2 years later (Table 5). Considering the absence of the yellow-necked mouse in the large samples from the years 2005-2006, one might expect that the park near the centre of Warsaw was colonized at the beginning of the twentyfirst century at the earliest and most likely in the second half of the first decade of the 2000s.

The behaviour of city populations of several species differs from that of populations dwelling in natural or seminatural habitats because of the presence of people (Gliwicz et al. 1994; Luniak 2004; Ditchkoff et al. 2006). Human noise has been shown to affect the behaviour of the yellow-necked mouse, which shortens the distance of movements (Pieniążek et al. 2017). Human disturbance could modify the activity of newly formed synurbic populations. The species is known for its high level of movements (Montgomery and Gurnell 1985) both on ground and climbing on trees (Štěpánková and Vohrálik 2009), which could have translated into a slightly higher risk of attacks by the tawny owl than seen in, for example, the striped field mouse. Moreover, the two rodent species differ in their peak activity times: the yellow-necked mouse is most active in the night (Wójcik and Wołk 1985; Kołakowski et al. 2018), while the striped field mouse can be active in any time and has a high activity percentage in the daytime (Gliwicz and Kryštufek 1999; Gryz et al. 2008; Tulis et al. 2016). If this difference in activity times was true in city parks, then the observed percentage contribution of the yellow-necked mouse to the owl's diet would be slightly greater than its actual proportion in the small mammal community.

In the forests outside the town, no increase (but sometimes a decrease, such as that observed in Klembów or Natolin near Nur - Table 3) in the contribution of the yellow-necked mouse to owl diets has been noted in recent decades. This might suggest the lack of a generally increasing trend of this rodent in central Poland. The colonization of Warsaw and the expansion of this species into urban areas might be an effect of local adaptations to urban life similar to that observed earlier in the striped field mouse and common pine vole Microtus subterraneus (Andrzejewski et al. 1978; Goszczyński et al. 1993; Lesiński, Gryz 2012). Since the yellow-necked mouse is a highly competitive species in comparison with other small rodents (Gliwicz 1981), one may expect that the structure of small mammal communities in the wooded areas of the Warsaw agglomeration will soon change significantly. Thus far, there is no definitive evidence of the exclusion of the striped field mouse by the yellow-necked mouse, although our preliminary data might suggest a slight decline of the first species. To demonstrate this, one should undertake monitoring of both populations in the Warsaw area, especially in central quarters of the city. Both the trapping method and analysis of owl diets should be used for this purpose.

Open Access This article is licensed under a Creative Commons Attribution 4.0 International License, which permits use, sharing, adaptation, distribution and reproduction in any medium or format, as long as you give appropriate credit to the original author(s) and the source, provide a link to the Creative Commons licence, and indicate if changes were made. The images or other third party material in this article are included in the article's Creative Commons licence, unless indicated otherwise in a credit line to the material. If material is not included in the article's Creative Commons licence and your intended use is not permitted by statutory regulation or exceeds the permitted use, you will need to obtain permission directly from the copyright holder. To view a copy of this licence, visit http://creativecommons.org/licenses/by/4.0/.

\section{References}

Abt KF, Bock WF (1998) Seasonal variations of diet composition in farmland field mice (Apodemus spp.) and bank voles (Clethrionomys glareolus). Acta Theriol 43:379-389

Amori G, Hutterer R, Kryštufek B, Yigit N, Mitsain G, Palomo LJ (2016) Apodemus flavicollis (errata version published in 2017). The IUCN Red List of Threatened Species 2016: e.T1892A115058023. https:// doi.org/10.2305/IUCN.UK.2016-3.RLTS.T1892A22423256.en. Downloaded on 12 September 2019

Andrade A, de Menezes JFS, Monjeau A (2016) Are owl pellets good estimators of prey abundance? J King Saud Univ Sci 28:239-244

Andrzejewski R, Babińska-Werka J, Gliwicz J, Goszczyński J (1978) Synurbization processes in population of Apodemus agrarius. I. Characteristics of populations in an urbanization gradient. Acta Theriol 23:341-358

Angold PG, Sadler JP, Hill MO, Pullin A, Rushton S, Austin K, Small E, Wood B, Wadsworth R, Sanderson R, Thompson K (2006) Biodiversity in urban habitat patches. Sci Total Environ 360:196204

Baker PJ, Ansell RJ, Dodds PA, Webber CE, Harris S (2003) Factors affecting the distribution of small mammals in an urban area. Mammal Review33:95-100

Bąkowski C, Kozakiewicz M (1988) Effects of a forest road on bank vole and yellow-necked mouse populations. Acta Theriol 72:245-252

Baranauskas K, Balčiauskas L, Mažeikytė R (2005) Vilnius city theriofauna. Acta Zool Litu 15:228-238

Buckmaster A, Osborne W, Webb N (2010) The loss of native terrestrial small mammals in large urban reserves in the Australian Capital Territory. Pac Conserv Biol 16:36-45

Cavia R, Cueto GR, Suárez OV (2009) Changes in rodent communities according to the landscape structure in an urban ecosystem. Landsc Urban Plan 90:11-19

Chernousova NF (1996) Effect of urbanization on communities of small mammals in park-forests in a large industrial center. Russ J Ecol 27: 286-292

Dickman CR, Doncaster CP (1987) The ecology of small mammals in urban habitats. I Populations in a patchy environment. J Anim Ecol 56:629-640 
Ditchkoff SS, Saalfeld ST, Gibson CJ (2006) Animal behavior in urban ecosystems: modifications due to human-induced stress. Urban Ecosyst 9:5-12

Drożdż A (1966) Food habits and food supply of rodents in the beech forest. Acta Theriol 11:363-384

Elvers H, Elvers KL (1984) Verbreitung und Ökologie der Waldmaus (Apodemus sylvaticus) in Berlin (west). Zool Beitrage 28:403-415

Garden JG, McAlpine CA, Possingham HP (2010) Multi-scaled habitat considerations for conserving urban biodiversity: native reptiles and small mammals in Brisbane, Australia. Landsc Ecol 25:1013-1028

Gliwicz J (1981) Competitive interactions within a forest rodent community in Central Poland. Oikos 37:353-362

Gliwicz J, Goszczyński J, Luniak M (1994) Characteristic features of animal populations under synurbization - the case of the blackbird and of the striped field mouse. Memorabilia Zool 49:237-244

Gliwicz J, Kryštufek B (1999) Apodemus agrarius. In: Mitchell-Jones AJ, Amori G, Bogdanowicz W, Kryštufek B, Reijnders PJH, Spitzenberger F, Stubbe M, Thissen JBM, Vohralík V, Zima J (eds) The atlas of European mammals. Academic Press, London, UK

Gomes V, Ribeiro R, Carretero MA (2011) Effects of urban habitat fragmentation on common small mammals: species versus communities. Biodivers Conserv 20:3577-3590

Gortat T, Barkowska M, Gryczyńska-Siemiątkowska A, Pieniążek A, Kozakiewicz A, Kozakiewicz M (2014) The effects of urbanization - small mammal communities in a gradient of human pressure in Warsaw city, Poland. Pol J Ecol 62:163-172

Gortat T, Rutkowski R, Gryczyńska A, Kozakiewicz A, Kozakiewicz M (2016) The spatial genetic structure of the yellow-necked mouse in an urban environment - a recent invader vs. a closely related permanent inhabitant. Urban Ecosyst 20:581-594

Goszczyński J, Jabłoński P, Lesiński G, Romanowski J (1993) Variation in diet of Tawny Owl Strix aluco L. along an urbanization gradient. Acta Ornithol 27:113-123

Gryz J, Krauze D (2008) Mortality of vertebrates on a road crossing the Biebrza Valley (NE Poland). Eur J Wildl Res 54:709-714

Gryz J, Krauze D, Goszczyński J (2008) The small mammals of Warsaw as inferred from tawny owl (Strix aluco) pellet analyses. Ann Zool Fenn 45:281-285

Gryz J, Krauze-Gryz D (2019) The common buzzard Buteo buteo population in a changing environment, Central Poland as a case study. Diversity 11(3):35

Gryz J, Krauze-Gryz D, Jasińska K, Brach M, Kowal P, Bolibok L, Werka J (2017a) Colonisation of Warsaw by red fox Vulpes vulpes - is it already a problem? In: Borowski Z, Olech W, Suchecka A (eds.) Book of abstracts 11 th European Vertebrate Pest Management Conference, Warsaw, Poland, 25-29 September, p 27

Gryz J, Lesiński G, Krauze-Gryz D, Stolarz P (2017b) Woodland reserves within an urban agglomeration as important refuges for small mammals. Folia For Pol 59(1):3-13

Gryz J, Ożga L, Krauze-Gryz D (2019) Long-term stability of tawny owl (Strix aluco) population despite varying environmental conditions a case study from Central Poland. Pol J Ecol 67:75-83

Heisler LM, Somers CM, Poulin RG (2015) Owl pellets: a more effective alternative to conventional trapping for broad-scale studies of small mammal communities. Methods Ecol Evol 7:96-103

Hille SM, Mortelliti A (2010) Microhabitat partitioning of Apodemus flavicollis and Myodes glareolus in the sub-montane Alps: a preliminary assessment. Hystix It J Mammal 21:157-163

Hodson NL (1960) A survey of vertebrate road mortality. Bird Study 7: 224-231

Hoffmeyer I (1973) Interaction and habitat selection in the mice Apodemus flavicollis and A. sylvaticus. Oikos 24:108-116

Juškaitis R (2000) Abundance dynamics of common dormouse Muscardinus avellanarius, fat dormouse Glis glis and yellow- necked mouse Apodemus flavicollis derived from nest box occupation. Folia Theriologica Estonica 5:42-50

Juškaitis R (2002) Spatial distribution of the yellow-necked mouse (Apodemus flavicollis) in large forest areas and its relation with seed crop of forest trees. Mamm Biol 67:206-211

Khlyap L, Glass G, Kosoy M (2012) Rodents in urban ecosystems of Russia and the USA. In: Triunveri A, Scalise D (eds) Rodents: habitat, pathology and environmental impact. Nova Science Pub Inc., New York, pp 1-22

Klimant P, Klimantová A, Baláž I, Jakab I, Tulis F, Rybanský L, Vadel L, Krumpálová Z (2017) Small mammals in an urban area: habitat preferences and urban-rural gradient in Nitra city, Slovakia. Pol J Ecol 65:144-157

Kołakowski M, Jancewicz E, Kielan E (2018) Czasowa i przestrzenna aktywność nornicy rudej Myodes (Clethrionomys) glareolus i myszy leśnej Apodemus flavicollis w siedlisku grądowym Puszczy Białowieskiej. Sylwan 162:1029-1037 (in Polish with English summary)

Krauze-Gryz D, Lesiński G, Pieniążek A, Romanowski J, Owsianka M, Prus M (2016) Ssaki Parku Skaryszewskiego w Warszawie. In: Romanowski J (ed) Park Skaryszewski w Warszawie - przyroda i użytkowanie. UKSW Press, Warsaw, pp 215-226 (in Polish with English summary)

Lesiński G (1998) Rozwój populacji sroki w peryferyjnej i podmiejskiej zabudowie Warszawy w latach 1983-1998. Kulon 3:185-193

Lesiński G, Fuszara E, Fuszara M, Kowalski M, Wojtowicz B (2001) The parti-coloured bat Vespertilio murinus in Warsaw, Poland. Myotis 39:21-25

Lesiński G, Gryz J (2012) How protecting a suburban forest as a natural reserve effected small mammal communities. Urban Ecosyst 15: $103-110$

Lesiński G, Ignaczak M, Manias J (2009) Opportunistic predation on bats by the tawny owl Strix aluco. Anim Biol 59:283-288

Lesiński G, Stolarz P (1999) Kręgowce w pokarmie puszczyka Strix aluco w Lesie Sobieskiego na peryferiach Warszawy. Kulon 1-2: 77-81 (in Polish with English summary)

Luniak M (2004) Synurbization - adaptation of animal wildlife to urban development. In: Shaw WW, Harris LK, VanDruff L (eds) Proceedings of the 4th International Symposium on Urban Wildlife Conservation. May 1-5, 1999, Tucson, Arizona, pp 50-55

Luniak M, Kozłowski P, Nowicki M, Plit J (2001) Ptaki Warszawy 1962-2000. Instytut Geografii i Przestrzennego Zagospodarowania PAN, Warsaw

Łopucki R, Kitowski I (2017) How small cities affect the biodiversity of ground-dwelling mammals and the relevance of this knowledge in planning urban land expansion in terms of urban wildlife. Urban Ecosyst 20:933-943

Łopucki R, Mróz I, Berliński Ł, Burzych M (2013) Effects of urbanization on small-mammal communities and the population structure of synurbic species: an example of a medium-sized city. Can J Zool 91: 554-561

Mahan CG, O'Connel TJ (2005) Small mammal use of suburban and urban parks in Central Pennsylvania. Northeast Nat 12:307-314

Marsh ACW, Harris S (2000) Partitioning of woodland habitat resources by two sympatric species of Apodemus: lessons for the conservation of the yellow-necked mouse (A. flavicollis) in Britain. Biol Conserv 92:275-283

Mazurkiewicz M, Rajska-Jurgiel E (1998) Spatial behavior and population dynamics of woodland rodents. Acta Theriol 43:137-161

McKinney ML (2008) Effects of urbanization on species richness: a review of plants nd animals. Urban Ecosyst 11:161-176

Mebs T, Scherzinger W (2000) Die Eulen Europas. Biologie, Kennzeichen, Bestände. Franckh-Kosmos-Verlag, Stuttgart

Mikulová P, Frynta D (2001) Test of character displacement in urban populations of Apodemus sylvaticus. Can J Zool 79:794-801 
Mitter G, Sumasgutner P, Gamauf A (2015) Niche-partitioning of three Apodemus species (Mammalia: Murinae) in an urban environment. Ann Naturhist Mus Wien 117:37-46

Montgomery WI (1999) Apodemus flavicollis. In: Mitchell-Jones AJ, Amori G, Bogdanowicz W, Kryštufek B, Reijnders PJH, Spitzenberger F, Stubbe M, Thissen JBM, Vohralík V, Zima J (eds) The atlas of European mammals. Academic Press, London, UK

Montgomery WI, Gurnell J (1985) The behaviour of Apodemus. In: Flowerdew JR, Gurnell J, JMW G (eds) The ecology of woodland rodents bank voles and wood mice. The proceedings of a symposium held at the Zoological Society of London on 23rd and 24th of November 1984. Symposia of the Zoological Society of London 55. Clarendon Press, Oxford, pp 89-115

Nowicki W (2001) Ptaki śródmieścia Warszawy. Muzeum i Instytut Zoologii PAN, Warsaw

Orłowski G, Nowak L (2006) Factors influencing mammal road kills in the agricultural landscape of South-Western Poland. Pol J Ecol 54: 283-294

Pérez-Barbería FJ (1991) Latitudinal differences in the contribution of bats to the barn owl diet. Ardeola 38:61-68 (in Spanish with English summary)

Pieniążek A, Boguszewski P, Meronka R (2017) The impact of urban noise on the behavior of two mouse species belonging to the genus Apodemus. Nat Resour 8:55-68

Popov VV (1993) Discriminant criteria and comparative study on morphology and habitat selection of Apodemus sylvaticus (Linnaeus, 1758) and Apodemus flavicollis (Melchior, 1834) (Mammalia, Rodentia, Muridae) in Bulgaria. Acta Zool Bulg 46:100-111

Pucek Z (ed) (1981) Keys to vertebrates of Poland: mammals. PWN, Warsaw

Pucek Z, Jędrzejewski W, Jędrzejewska B, Pucek M (1993) Rodent population dynamics in a primeval deciduous forest (Bialowieza National Park) in relations to weather, seed crop, and predation. Acta Theriol 38:199-232

Redpath SM (1995) Habitat fragmentation and the individual: tawny owls Strix aluco in woodland patches. J Anim Ecol 64:652-661
Ruprecht AL (1979) Kryteria identyfikacji gatunkowej podrodzaju Sylvaemus Ognev \& Vorobiev, 1923 (Rodentia, Muridae). Przegl Zool 23:340-349 (in Polish with English summary)

Simenowska-Nikolova DM (2007) Interspecific social interactions and behavioral responses of Apodemus agrarius and Apodemus flavicollis to conspecific and heterospecific odors. J Ethol 25:41-48

Štépánková J, Vohrálik V (2009) Vertical activity of the yellow-necked mouse (Rodentia: Muridae) at edge of a mixed forest. Folia Zool 58: 26-35

Stradiotto A, Cagnacci F, Delahay R, Tioli S, Nieder L, Rizzoli A (2009) Spatial organization of the yellow-necked mouse: effects of density and resource availability. J Mammal 90:704-714

Sunde P, Bølstad MS (2004) A telemetry study of the social organization of tawny owl (Strix aluco) population. J Zool 263:65-76

Tomiałojć L (1976) The urban population of the woodpigeon Columba palumbus Linnaeus, 1758, in Europe - its origin, increase and distribution. Acta Zool Cracov 21:585-631

Tulis F, Ambros M, Baláž I, Žiak D, Hulejová Sládkovičová V, Miklós P, Dudich A, Stollmann A, Kliment P, Somogyi B, Horvéth G (2016) Expansion of the striped field mouse (Apodemus agrarius) in the South-Western Slovakia during 2010-2015. Folia Oecologica 43: 64-73

Vergnes A, Kerbiriou C, Clergeau P (2013) Ecological corridors also operate in an urban matrix: a test case with garden shrews. Urban Ecosyst 16:511-525

Węgrzynowicz A (2013) Zmiany liczebności i umiejscowienie gniazd sroki Pica pica i wrony siwej Corvus cornix w Warszawie w latach 1974-2009. Ornis Pol 54:12-24 (in Polish with English summary)

Wendland V (1980) Der Waldkauze (Strix aluco) im bebauten Stadtgebiet von Berlin (west). Beiträge Vogelkunde 26:157-171

Wiącek J, Niedźwiedź M, Kowalczuk S, Piskorski M (2009) Skład pokarmu puszczyka Strix aluco na wybranych stanowiskach Lubelszczyzny. In: Wiącek J, Polak M, Kucharczyk M, Grzywaczewski G, Jerzak L (eds) Ptaki - Środowisko Zagrożenia - Ochrona. Wybrane aspekty ekologii ptaków. LTO, Lublin, pp 115-124 (in Polish with English summary)

Wójcik JM, Wołk K (1985) The daily activity rhythm of two competitive rodents: Clethrionomys glareolus and Apodemus flavicollis. Acta Theriol 30:241-258 